\title{
Analysis on Climate Literacy Capacity of Level XI High School Students in Surabaya
}

\author{
Hasna' Nabilah, *Eko Hariyono \\ Physics Education Department, Faculty of Mathematics and Science Education, Universitas \\ Negeri Surabaya. Jl. Ketintang, Kec. Gayungan, Surabaya, Indonesia 60231 \\ *Corresponding Author e-mail: ekohariyono@unesa.ac.id \\ Received: June 2021; Revised: June 2021; Published: June 2021
}

\begin{abstract}
The climate problem today caused damage to infrastructures and many other living elements among mankind. As the prospected future leaders, students need to understand and to respond the effects of climate change. A person with climate literacy may enhance their ability and capacity to face climate challenges in the future. Climate literacy is the understanding of the influence of self and society on the climate. This research is conducted to give a general picture of climate literacy among high school students in Surabaya and each indicator in climate competency aspects. The methodology used in this research is a descriptive qualitative method. The research instrument used in this research is a climate literacy test. The valuation of climate literacy capacity of the students being done by giving scores manually from the test answers according to the scoring guideline in the scoring rubric and achievement results with categories as very high, high, moderate, low, and very low. The research samples are 107 high school students at level XI in SMAN 22 Surabaya (Public High School 22 Surabaya). According to the research, the students' indicator in scientific identifying is low with a score percentage of $48.9 \%$. The students' indicator in explaining the scientific phenomenon is moderate with a score of $74.5 \%$, while students' indicator score in using scientific evidence is moderate with $68.6 \%$. It could be said that high school students in SMAN 22 Surabaya as a whole have a moderate climate literacy capacity with a percentage score of $64 \%$.
\end{abstract}

Keywords: Climate Literacy; Competency Aspect; Climate Change

How to Cite: Nabilah, H., \& Hariyono, E. (2021). Analysis on Climate Literacy Capacity of Level XI High School Students in Surabaya. Prisma Sains : Jurnal Pengkajian Ilmu dan Pembelajaran Matematika dan IPA IKIP Mataram, 9(1), 28-37. doi:https://doi.org/10.33394/j-ps.v9i1.3816

\section{INTRODUCTION}

Climate change is a real threat to the civilization of mankind. Because of climate change, people felt an extreme climate intensely. Everything that correlates with climaterelated phenomena or climate change is predicted to destroy and disrupt social systems, infrastructures, even ecosystems. Global act to cut greenhouse gas emissions may decrease the risk of tremendous climate change (USGCRP, 2018).

According to Wolff (Julismin, 2013), problems of climate change have already occurred since the 1900s. Some indicators that become the factors of climate change have been observed with the climate temperature rise to 0.8-degree Celcius or 14-degree Fahrenheit. The rise of climate temperature is aligned with the raise of the warming sea temperature which impacted the melting of ice in the North Pole and the South Pole in an immense number. Extreme weather could also be used as an indicator of climate change.

In Indonesia, some temperature climate data has been gained through the observation data of BMKG (Meteorological, Climatological, and Geophysical Agency) from the year 1981 to 2018. Climate temperature rose 0.03-degrees Celcius in each year wherein 30 years the temperature raise in locations would reach 0.9-degree Celcius (BMKG, 2021). 
Climate change will impact temperature raise that would make the climate condition extreme. The temperature rise in the Earth will influence the rise of sea level that may lead to floods and storms due to extreme weathers that could consequence in the change of habitats and even the extinction of many species such as animals, plants, and other living organisms (Haryanto \& Prahara, 2019). Other than that, the phenomenon of high rainfall also often be related to a strong climate condition and the variability of the climate (Espinosa et al., 2021).

The phenomenon of climate crisis in the environment is a real threat. Limitation on global warming should be done to decrease the crisis impact up to 1.5-degrees Celcius, as has been decreed by Paris Agreement. Strict actions will decrease greenhouse gas emission that related with climate change (Ccpi.org, 2021).

Some problems in life are related to education because everything is stemmed from education. Everything done by mankind is due to the process of learning. With that being said, education is without a doubt needed to sustain every sector of living, especially in social life. The education process should take the role of increasing knowledge and improving the character of society. The same thing works in the problems of climate change, the reason for its occurrence and its prevention could be related to education.

As an attempt to increase awareness towards society on the climate change phenomenon, an act to do internalization in issues of climate change is important to be done in education. Through climate change education, it will shape the alertness of the people in facing the impacts of climate change (Menlhk.go.id, 2021). Because students when faced with a daily phenomenon will train also demand them in a high level of thinking to solve the problems faced (Septaria et al., 2019). As well as climate phenomena that must be handled immediately.

Right now, education in 2030 sustainable development is being intensified by OECD (Organization for Economic, Cooperation, and Development). OECD intensify the mission to discuss issues that in dire of immediate solutions, such as the problem of climate change that impacted the world. According to the previous researches, physics education that integrates climate act with SDGs principle is one of the solutions to prepare a strong society towards global change (Hartati \& Hariyono, 2019).

For more than a decade, Indonesia that has participated in PISA (Program for International Students Assessment) still puts the competence of Indonesian students in low criteria (Sasmita et al., 2020). PISA is a program conducted by nations that are enjoined in OECD. Indonesia's achievement level is still seen at a lower level compared to other participating nations. This could be seen from Indonesian achievement in 2015 that only got the ranking of $62^{\text {th }}$ out of 69 participating nations (OECD, 2016) while in 2019, Indonesia still ranked in $70^{\text {th }}$ out of 78 participating nations, where Indonesia is still on level 1a which is ranked low related with its level of science literacy (OECD, 2020).

From the occurrence of climate change phenomenon today, society is hoped to understand it and know the proper action as a solution to respond towards climate change, thus students are also hoped to be prepared with the future challenges to be able to face the problems of climate change. Having said that, a platform that could produce authentic solutions from its people is needed to face climate change, where one of it is related to literacy.

Climate literacy as an attempt of environment education will open the knowledge of people in the real-life regarding the climate change condition in the environment. By understanding climate literacy, mankind may increase their self-capacity to face the climate challenges in the future to achieve a better life for mankind. It is written in some literature that school has an important role because children and teenagers are facing problems in conceiving climate change and negotiating their community to be more emphatic towards climate change (Jorgenson et al., 2019). Teenagers need to have climate literacy. With climate literacy, teenagers will be more motivated to participate and to play their role in decreasing the impact of climate change (Luthfia et al., 2019). 
People that understand climate literacy will have a basic understanding of the climate system, including the factors of climate change influenced by nature and mankind, until they understand the relationship between climate with the life of mankind. They will have the capacity to analyze the validity of scientific arguments on climate and thus use that information to support their policies (Research, 2009) until they understand the importance to do real acts in decreasing the impact of climate change in their daily life.

Climate literacy is part of science literacy, "Science, mathematics, and technology have a tremendous impact in the living of an individual and our culture. Understanding science will help us to understand the phenomenon in the world, to give information for our personal and public policies, and as a basis for learning for the rest of one's life." (Research, 2009).

UNEP (in the book of Kementerian Pendidikan dan Kebudayaan, 2017) said that the key of science literacy is to face lots of the challenges of the XXI century to fulfill basic needs of water and food, generating sufficient energy, suppressing diseases, and facing climate change. With an actual scope of science literacy, climate literacy will be able to be related and thus goes into the context of its application in science literacy (Azevedo \& Marques, 2017).

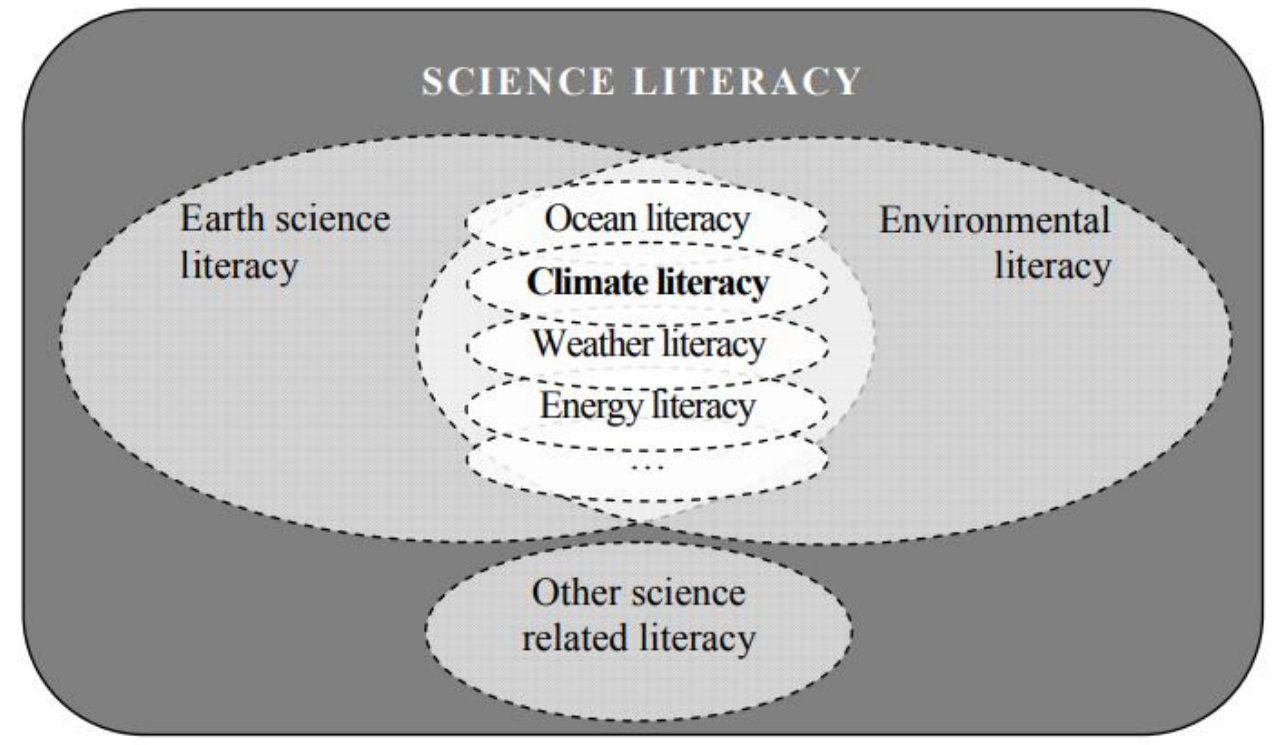

Figure 1. Visualization on the relation of climate literacy and science literacy (Azevedo \& Marques, 2017).

Azevedo said that some reviewers connected climate literacy with science literacy and other literacy as how seen in the Figure 1. Because of that, climate literacy indicators that being used are adapted from science literacy indicators, especially from the competency aspect (Ekayanti \& Hariyono, 2020). From the problem of the low science literacy level in Indonesia and the importance of the 2030 sustainable development education that being acted by OECD, thus these two realities could be met in harmony to create a competency analysis towards climate literacy. As the leaders of the future and knowledgeable citizens, students need to understand and to respond the impact of climate change.

In today's reality, the youth's knowledge of science and their perception towards climate change is still not much been checked, especially in a huge-scaled study (Oliver \& Adkins, 2020). Offering individual abilities that can be shared with many people is the importance of deepening literacy (Dewantara et al., 2019).

The results of the study (Cacundangan \& Garcia, 2017) describe students in Kabacan, North Cotabato have some knowledge with a low degree of certainty on the basic concepts, causes, effects, and mitigations of the occurrence of climate change and knowledge about the causes of climate change is not shared. In addition (Kuthe et al., 2020) in their research created a project aimed at improving climate literacy in German and Austrian teenagers and 
in this project produced data that participating teenagers who have different weaknesses regarding climate literacy can still be largely overcome. These results should be confirmed in future studies to young people from other countries or of various ages.

While the difference between this research and relevant research is to give an idea of the extent of climate literacy skills of grade 11 students located in Surabaya, Indonesia. This study refers more to the competency aspect with the three accompanying indicators. So that from the three indicators as a whole will be known how the ability of each student with the criteria of the ability that has been determined.

With the background being elaborated, this research is conducted with the purpose to understand the climate literacy of high school students in level XI in Surabaya in general and each of the indicators relating to climate competency aspects.

\section{METHOD}

\section{Research Design}

The research methodology that is used is a descriptive-qualitative methodology with the usage of the test instrument. This research is conducted without giving special treatment whether it is manipulation or changing the variables, but it gives the picture of the condition as it is (Sukmadinata, 2012), thus there is no need to enact a class control or class experiment in this matter.

\section{Research Subjects}

This research is conducted in SMAN 22 Surabaya (Public High School 22 Surabaya). The population in this research is all students in level XI that is registered in SMAN 22 Surabaya. The technique in picking the samples is by picking three classes which are XI MIA (Mathematics and Science) 1 class, XI MIA 4 class, and XI MIA 5 class. All of the students in the mentioned class are the subjects with 107 students in total.

\section{Research Instrument}

The test instrument used is in essay and multiple choices type with nine questions in total. The instrument used in this research is adapted from some test questions from PISA and equipped with a scoring format and rubric that has been developed by researchers. After that, the instrument is validated by consulting the experts to rate the point validity by comparing the significant value in the SPSS output in pearson correlation row at a significant level of $5 \%$. When the Sig. (2-tailed) value is $<0.05$ and the pearson correlation is $(+)$, thus the test questions became valid. If the Sig. (2-tailed) $<0.05$ and the pearson correlation is (-), then the test questions became invalid (Haryadi \& Mulyani, 2020) where it leads to the result as below (Table $1 \&$ Table 2).

Table 1. Instrument Validity

\begin{tabular}{ccc}
\hline Dimension & Sig. (2-tailed) & Details \\
\hline Indicator 1 & 0.00 & valid \\
Indicator 2 & 0.00 & valid \\
Indicator 3 & 0.00 & valid \\
\hline
\end{tabular}

According to the SPSS output result SPSS above, it is known that if every indicator question of 1,2, and 3 has a significant value or p-value between the questions with the total score less than 0.05 , thus the test question in the instrument becomes invalid.

Table 2. Instrument Reliability

\begin{tabular}{ccc}
\hline Dimension & Alpha Cronbach & Details \\
\hline Indicator 1 & 0.923 & reliable \\
Indicator 2 & 0.760 & reliable \\
Indicator 3 & 0.670 & reliable \\
\hline
\end{tabular}


The instrument reliability test in this research is using the alpha cronbach $(\alpha)$ method. The criteria of reliable research with alpha cronbach technique are when the reliability coefficient $\mathrm{rn}>0.6$ (Siregar, 2013). According to the reliability test result above, it is known that every indicator has the alpha cronbach value higher than 0.6 , thus every test question is reliable and is ready to be used in the research.

\section{Research Procedure}

The research is conducted through several phases which are preparation, execution, and the final phase. In the preparation phase, researchers decided the schools be researched, meeting the teachers to communicate and to coordinate, and then to receive a permit letter to conduct the research. In the execution phase, the researchers spread the climate literacy test instrument to the students who became the research samples. In the last phase, the researchers processed, analyzed the data, and giving a conclusion from the research that has been done.

\section{Data Analysis}

The method to gain the climate literacy competency score of the students is by giving the scores manually through the test answers data according to the scoring guideline in the scoring rubric. The calculation result of the climate literacy competency could be done by using adapted research (Rajagukguk, 2015), where the climate literacy competency values of the students are converted into percentage by the method as below :

Details :

$$
N p=\frac{R}{S M} x 100 \%
$$

NP : Climate change literacy competency percentage (\%)

$\mathrm{R}$ : Acquired score from correct answers

SM : Maximum score from the test

100 : Fixed numbers

From these acquired percentage data, the scoring result from the students could be categorized into criteria of very high, high, moderate, low, and very low (Rajagukguk, 2015) as shown in the Table 3 below.

Table 3. Climate Literacy Capacity Criteria

\begin{tabular}{ccc}
\hline No. & Categories & Percentage \\
\hline 1. & Very High & $86-100 \%$ \\
2. & High & $76-85 \%$ \\
3. & Moderate & $60-75 \%$ \\
4 & Low & $55-59 \%$ \\
5 & Very Low & $\leq 54 \%$ \\
\hline
\end{tabular}

\section{RESULTS AND DISCUSSION}

After the research, the median of the final total percentage score resulted in $64 \%$. According to the existing theory, it could be said from that score result that the climate students' change literacy competency is categorized as 'moderate'. And when it is analyzed deeper, it will be exposed that each student have their excellence from the total acquired score in answering climate literacy questions. These points are summarized in the Figure 2. 


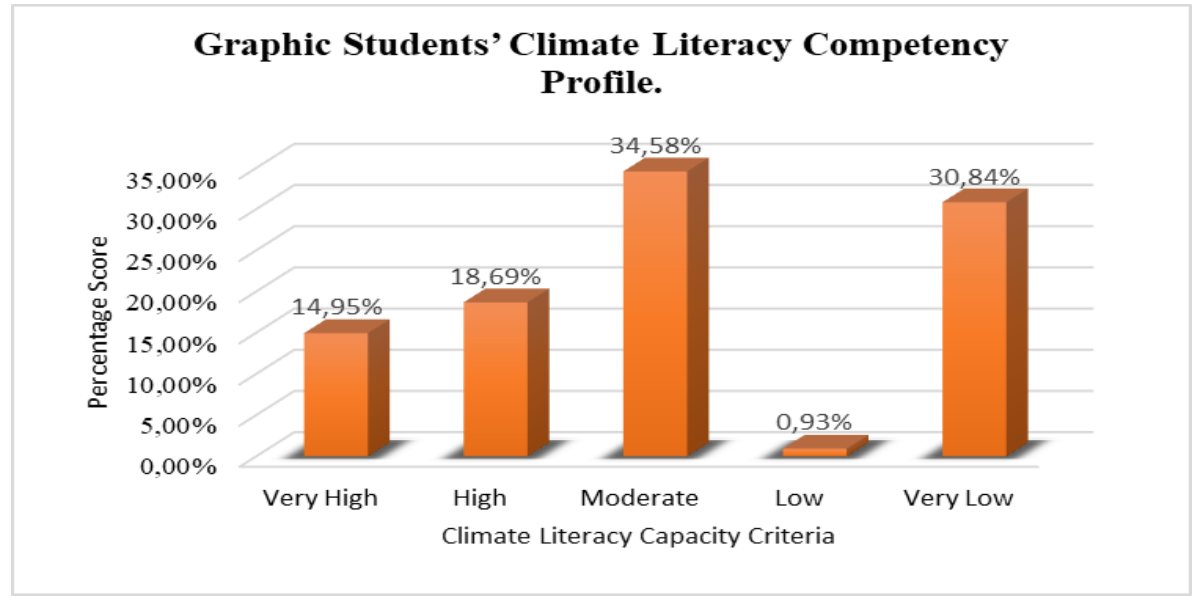

Figure 2. Students' Climate Literacy Competency Profile.

In detail, the total calculated percentage of $14.95 \%$ or 16 students are categorized into 'very high' in their climate literacy mastery, 20 students (18.69\%) are categorized as high in their climate literacy mastery. Students who acquired a moderate level of climate literacy mastery are 37 students $(34.58 \%)$. There is only one student $(0.93 \%)$ that acquired the low level of climate literacy mastery while the rest of them which are 33 students $(30.84 \%)$ is acquired a very low level of climate literacy mastery, from 107 students in total. These numbers of the median from the acquired score have shown that most of the students are having a moderate level of climate literacy competency, thus it is acquired that the students' understanding regarding climate-related phenomenon is moderate.

Climate literacy capacity itself is something that should be had by students because people with climate literacy may use their knowledge to enrich their calculation in deciding their life policies for a better quality of living because they grasp the basic understanding of the climate change system, including the factors that also affected by nature as well as mankind (Research, 2009). One of the aspects of climate literacy is the competency aspect where it refers to the mental process that is involved when a person answering a test or solving a problem (Nurdin, 2019). The competency aspect that is acquired in climate literacy will be related to the mental process when one answers some questions that referring to solving problems in the process to prevent climate change.

The competency aspect is rated from several indicators. A total indicator that is analyzed from competency aspects is three, which are identifying scientific issues, explaining a scientific phenomenon, and using scientific evidence. The climate literacy competency result in the competency aspects is as shown Figure 3.

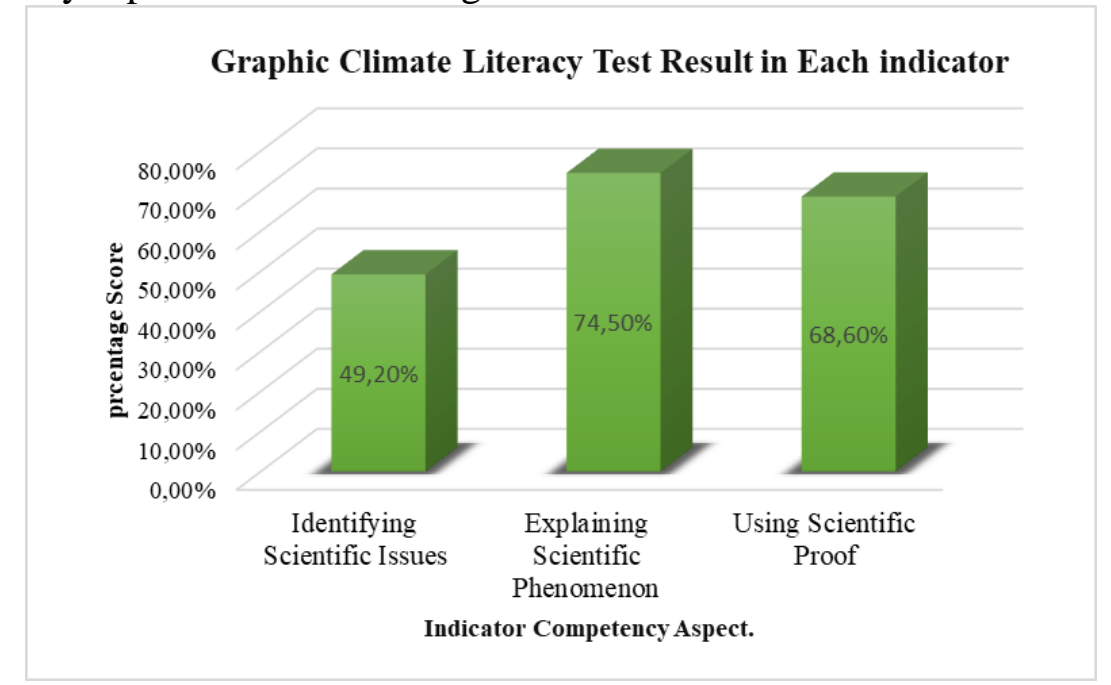

Figure 3. The Climate Literacy Test Result in Each indicator According to Competency Aspect. 
The result from the acquired percentage is gained from finding the gained maximum score from students and finding the median from the literacy capacity in each existing indicator (Wulandari \& Sholihin, 2016). From the score percentage that is acquired, it will be found how is the students' criteria in climate literacy competency criteria in each indicator, where it would lead to the categorization in the Table 4.

Table 4. Climate Literacy Criteria Mastery in Each Indicator.

\begin{tabular}{ll}
\hline Competency Aspect Indicators & Mastery Criteria \\
\hline Identifying Scientific Issues & Very Low \\
\hline Explaining Scientific Phenomenon & Moderate \\
\hline Using Scientific Proof & Moderate \\
\hline
\end{tabular}

According to the research data on students' answers in the climate literacy test, Based Figure 3 and Table 4 the highest percentage of the result is in the indicator of explaining a scientific phenomenon that achieved $74.5 \%$, thus categorized as moderate. It is then followed by the indicator of using scientific proof. And the least number of percentages is in the indicator of identifying scientific issues with the number of $49.2 \%$, thus categorized as very low.

As Yuliati (Erniwati et al., 2020) said that competency aspect will be related to how the students or the individual will applicate their knowledge in the real world. According to the result of the students' mastery in the indicator of identifying scientific phenomena which are scored as very low, it could be said that the students' competency in solving issues relating to the factors of climate change and its relations with their daily life is very low. In the process of the test, the average students still answer the answers regarding climate in a wrong manner.

The capacity in identifying climate scientific issues will show how capable the students are in understanding the issues and their characteristics in each key words of the climate phenomenon that is in the climate change test instrument. This is related to the basic knowledge of the basic concepts of climate change because the analysis questions in the test are correlating students' cognitive aspects with daily climate phenomena and occurrences. Thus, the students' capacity in identifying scientific issues in climate literacy is related to the cognitive memory quality of students.

From the research, it could be said that the students' achievement in indicator in identifying scientific keywords to solve climate problems is still low, compared to the other indicators. Some students are still wrong in identifying the greenhouse gas effect that being related to the climate change phenomenon and in identifying the gasses that caused the greenhouse gas effect. In this test, students are expected to understand that climate change is caused by the raise of the greenhouse gas effect. The rise of the greenhouse gas effect could be the factor that catalyzes the global warming process, thus this effect will raise the frequency of extreme weathers (Pabalik et al., 2015).

From the research result on students' indicators in using scientific evidence, it could be said that the students as a whole have some competency in answering the questions. Students could interpret scientific evidence and deriving conclusions by laying out data that is available in some tables and pictures in the climate change test instrument. Other than that, the capacity to use scientific evidence is shown through their way of identifying assumptions, proofs, and reasons behind the conclusions derived in solving the problems of climate change.

The majority of the students could give information explanations in the median temperature of earth's atmosphere graphic and carbon dioxide emission in earth graphic that could support the explained conclusion in the question. This could be seen from the fact that some students answered with information that they found in supporting the conclusion that carbon dioxide emission and the average temperature of the atmosphere is gradually increasing each year, except some specific years that caused a not significant temperature 
decrease. Thus, from the answers to the climate literacy test, students may read a graphic and give conclusions with a moderate level of mastery. The capacity to interpret data and scientific evidence could be seen from their method in changing data into one interpretation towards another interpretation.

Some scientific evidence that was used is from reliable sources could be reinterpreted and selected by students that indirectly lead students into the solutions of the problems (Asyhari, 2015), thus in this climate literacy students could see the graphic data to be lead to an understanding regarding climate change thus to acquire the solution from the problem.

The students' capacity in explaining scientific phenomenon as one of the indicators is categorized as moderate. Overall, students could explain scientific phenomena relating to climate change where students applied scientific knowledge in situations given in the process of daily activities that may reduce climate change. Other than that, students have competency in describing or interpreting phenomena on the processing of items that may cause the rise of temperature thus concluding into climate change.

The acquired data also explained that the students' capacity in explaining the scientific phenomenon is pretty good in their application of some knowledge of climate change towards each condition given in the test. In this matter, students may predict that the cause of climate change could be caused by man's actions. Students also could interpret or describing phenomena and predict some activity that may decrease the carbon dioxide emission as prevention of climate change, because it may lead to the rise of temperature thus concluding into an extreme climate situation. This capacity achievement also gives information that students could give explanations very well in the problems laid out in the test.

This shows that students' capacity in applying their knowledge of climate change in solving climate literacy questions is moderate. The knowledge concept that they have will influence their capacity in describing or interpreting scientific phenomenon (Rini et al., 2021), thus the average students could already explain the phenomenon in climate change.

In this manner, it is seen that climate literacy education as a whole could be improved further, especially in the learning that could be related to each climate occurrence that has happened lately. Other than knowing how the climate phenomenon happened, students could be given guidance in how to prevent climate change and to respond correspondingly towards climate changes today. The role of teachers is important to teach climate change that may develop students into being critical in gaining new information on phenomenon thus becoming an emphatic individual that is committed to taking actions to make their environment better (Chang, 2015).

\section{CONCLUSION}

The result of the research shows that on average the score of climate literacy capacity of level XI high school students of 107 students in SMAN 22 Surabaya is moderate. While the result for each indicator is acquired that students could explain a scientific phenomenon and using scientific evidence at a moderate level, while still low in identifying scientific issues. In this manner, it is seen that as a whole that climate literacy quality should be improved, especially in things regarding the prevention of climate change.

\section{RECOMMENDATION}

The results of this study are limited to the ability of students in climate literacy so in the next study it is expected that there are innovations and new ideas that are studied more deeply to find ways to improve students' ability to climate literacy.

\section{ACKNOWLEDGMENT}

Researchers thank SMA 22 Surabaya who has allowed to research and take data there and fully support the implementation of this research. 


\section{REFERENCES}

Asyhari, A. (2015). Profil Peningkatan Kemampuan Literasi Sains Siswa Melalui Pembelajaran Saintifik. Jurnal Ilmiah Pendidikan Fisika Al-Biruni, 4(2), 179-191. https://doi.org/10.24042/jpifalbiruni.v4i2.91

Azevedo, J., \& Marques, M. (2017). Climate literacy: A systematic review and model integration. International Journal of Global Warming, 12(3-4), 414-430. https://doi.org/10.1504/IJGW.2017.084789

BMKG. (n.d.). Tren Suhu. https://www.bmkg.go.id/iklim/?p=tren-suhu

Cacundangan, K. L., \& Garcia, M. E. Z. (2017). Students' Climate Change Literacy: Implication for Climate Change Education in Public Secondary Schools in Kabacan, North Cotabato. Cebu International Conference on Agricultural, Chemical, Biological and Environmental Sciences (ACBES-17), 187-193. https://doi.org/10.17758/uruae.dir0117204

Ccpi.org. (2021). Climate Change Performance index. Retrieved from https://ccpi.org/

Chang, C. H. (2015). Teaching Climate Change - A Fad or a Necessity? International Research in Geographical and Environmental Education, 24(3), 181-183. https://doi.org/10.1080/10382046.2015.1043763

Dewantara, D., Mahtari, S., Misbah, M., \& Haryandi, S. (2019). Student Responses in Biology Physics Courses Use Worksheets Based on Scientific Literacy. Prisma Sains : Jurnal Pengkajian Ilmu Dan Pembelajaran Matematika Dan IPA IKIP Mataram, 7(2), 192-197. https://doi.org/10.33394/j-ps.v7i2.2040

Ekayanti, N. E., \& Hariyono, E. (2020). SETS Vision: How To Develop Students' Climate Literacy Through Physics Learning? Inovasi Pendidikan Fisika, 09(02), 215-222.

Erniwati, Istijarah, Tahang, L., Hunaidah, Mongkito, V. H. R., \& Fayanto, S. (2020). Kemampuan Literasi Sains Siswa SMA Di Kota Kendari: Deskripsi \& Analysis. Jurnal Kumparan Fisika, 3(2), 99-108. https://doi.org/10.33369/jkf.3.2.99-108

Espinosa, L. A., Portela, M. M., Filho, J. D. P., \& Zelenakova, M. (2021). Bivariate Modelling of a Teleconnection Index and Extreme Rainfall in a Small North Atlantic Island. Climate, 9(86), 1-21. https://doi.org/10.3390/cli9050086

Hartati, M., \& Hariyono, E. (2019). Efektifitas Pembelajaran Fisika Terintegrasi Dengan Aksi Iklim Pada Prinsip Sdgs (Sustainable Development Goals) Dalam Meningkatakan Karakter Peduli Lingkungan. IPF: Inovasi Pendidikan Fisika, 09(03), 349-355.

Haryadi, H., \& Mulyani, E. (2020). Pengaruh Bauran Pemasaran Terhadap Keputusan Pembelian Mesin Gasmin Dari Beberapa Industri Tahu di Kabupaten Sumedang. Jurnal Teknologi Mineral Dan Batubara, 16(3), 165-177. https://doi.org/10.30556/jtmb.Vol16.No3.2020.1051

Haryanto, H. C., \& Prahara, S. A. (2019). Perubahan Iklim, Siapa Yang Bertanggung Jawab? Insight: Jurnal Ilmiah Psikologi, 21(2), 50-61. https://doi.org/https://dx.doi.org/10.26486/psikologi.v21i2.811

Jorgenson, S. N., Stephens, J. C., \& White, B. (2019). Environmental education in transition: A critical review of recent research on climate change and energy education. The Journal of Environmental Education, 50(3), 160-171. https://doi.org/10.1080/00958964.2019.1604478

Julismin. (2013). Dampak dan Perubahan Iklim di Indonesia. Jurnal Geografi, 5(1), 40-46. https://doi.org/10.24114/jg.v5i1.8083

Kuthe, A., Körfgen, A., Stötter, J., \& Keller, L. (2020). Strengthening their climate change literacy: A case study addressing the weaknesses in young people's climate change awareness. Applied Environmental Education and Communication, 19(4), 375-388. https://doi.org/10.1080/1533015X.2019.1597661

Luthfia, A. R., Alimin, N. A., Febriani, S. A. ., \& Alkhajar, E. N. . (2019). Penguatan Literasi Perubahan Iklim di Kalangan Remaja. ABADIMAS ADI BUANA, 03(1), 39-42. https://doi.org/https://doi.org/10.36456/abadimas.v3.i1.a1941 
Menlhk.go.id. (2021). Internalisasi Perubahan Iklim dalam Kurikulum Pendidikan. 21 Maret. http://www.menlhk.go.id/site/single_post/3729/internalisasi-perubahan-iklim-dalamkurikulum-pendidikan

Nurdin. (2019). Urgensi Literasi Sains Dalam Meningkatkan Kompetensi Widyaiswara PAI BDK Aceh Di Era Millenial. Jurnal Pendidikan Sains Indonesia, 07(01), 55-63. https://doi.org/10.24815/jpsi.v7i1.12476

OECD. (2016). Country Note - Results from PISA 2015: Indonesia. https://www.oecd.org/pisa/PISA-2015-Indonesia.pdf

OECD. (2020). PISA 2018 Results (Volume VI): Are Students Ready to Thrive in an Interconnected World? PISA,OECD Publishing, Paris. https://doi.org/10.1787/d5f68679-en.

Oliver, M. C., \& Adkins, M. J. (2020). "Hot-headed" students? Scientific literacy, perceptions and awareness of climate change in 15-year olds across 54 countries. Energy $\begin{array}{llll}\text { Research and Social } & \text { Science, } & 701641 .\end{array}$ https://doi.org/10.1016/j.erss.2020.101641

Pabalik, I., Ihsan, N., \& Arsyad, M. (2015). Analisis Fenomena Perubahan Iklim dan Karakteristik Curah Hujan Ekstrim di Kota Makassar. Jurnal Sains Dan Pendidikan Fisika, 11(1), 88-92. https://ojs.unm.ac.id/JSdPF/article/view/1470/540

Rajagukguk, W. (2015). Evaluasi Hasil Belajar Matematika. Pustaka Belajar.

Research, U. S. G. C. (2009). Climate Literacy: The Essential Principles of Climate Science. In Science (Issue March). Global Change Research Program. http://www.climatescience.gov

Rini, C. P., Hartantri, S. D., \& Amaliyah, A. (2021). Analisis Kemampuan Literasi Sains Pada Aspek Kompetensi Mahasiswa program Studi PGSD FKIP Universitas Muhammadiyah Tangerang. Jurnal Pendidikan Dasar Nusantara, 6(2), 166-179. https://doi.org/10.29407/jpdn.v6i2.15320

Sasmita, F. D., Arifuddin, M., \& Mahtari, S. (2020). The Effect of Diboracy (Digital Book Containing Scientific Literacy) in Reducing Misconceptions on Newton's Law of Gravity. Prisma Sains: Jurnal Pengkajian Ilmu Dan Pembelajaran Matematika Dan IPA IKIP Mataram, 8(2), 112-121. https://doi.org/10.33394/j-ps.v8i2.3164

Septaria, K., Dewanti, B. A., \& Habibbulloh, M. (2019). Implementasi Metode Pembelajaran Spot Capturing Pada Materi Pemanasan Global untuk Meningkatkan Keterampilan Proses Sains. Prisma Sains : Jurnal Pengkajian Ilmu Dan Pembelajaran Matematika Dan IPA IKIP Mataram, 7(1), 27-37. https://doi.org/10.33394/j-ps.v0i0.1379

Siregar, S. (2013). Metode Penelitian Kuantitatif: Dilengkapi Perbandingan Perhitungan Manual \& SPSS. Kencana Prenada Media Group.

Sukmadinata, N. S. (2012). Metode Penelitian Pendidikan. PT. Remaja Rosdakarya.

USGCRP. (2018). Impacts, Risks, and Adaptation in the United State: Fourth National Climate Assessment: Vol. II (R. D.r, A. C.W, E. D.r, K. K.E, L. K.L.M, M. T.K., \& B. . Stewart(eds.) (eds.); pp. 1-470). U.S. Global Change Research Program, Washington, DC, USA, 1515 pp. https://doi.org/10.7930/NCA4.2018

Wulandari, N., \& Sholihin, H. (2016). Analisis Kemampuan Literasi Sains Pada Aspek Pengetahuan Dan Kompetensi Sains Siswa Smp Pada Materi Kalor. Edusains, 8(1), 6673. https://doi.org/10.15408/es.v8i1.1762 